\title{
Experience Gained during the Decommissioning of the SSEC from the VVR-S Nuclear Research Reactor
}

\author{
R. Deju ${ }^{a, *}$, I. IORGA ${ }^{a, b}$ AND D. GURAU ${ }^{a}$ \\ ${ }^{a}$ Horia Hulubei National Institute for Physics and Nuclear Engineering, \\ POB MG-6, Magurele-Bucharest, 077125, Romania \\ ${ }^{b}$ Faculty of Physics, University of Bucharest, POB MG-11, Magurele-Bucharest, 077125, Romania \\ The VVR-S nuclear research reactor owned by Horia Hubulei National Institute of Physics and Nuclear \\ Engineering was designed for research and radioisotope production being permanently shut-down in 2002 after 40 \\ years of operation. The decommissioning of the reactor started in 2010 and is planned to be finalized in 2020, being \\ the first nuclear research reactor that has started the decommissioning project from the South-East of Europe. This \\ paper presents the lessons learned from the decommissioning of systems, structures, equipment and components \\ from pumps room. The experiences gained cover a diverse range of topics from planning, approval, radiological \\ characterization process made, dismantling, equipment used, resources, etc. Radiation protection and economics \\ are the key factors for the selection of technology for decommissioning. The evaluation of the available technology \\ has been made and areas for improving the technology have been identified. Dedicated and advanced technologies \\ were chosen to perform specific tasks. The project was planned well in advance. Safety aspects have been taken into \\ consideration. Resource constraints have also been an important issue considered in defining the decommissioning \\ strategy. Experiences and knowledge were presented and shared with the community.
}

DOI: 10.12693/APhysPolA.131.82

PACS/topics: 28.41.Te

\section{Introduction}

The final step in a nuclear facility lifetime after the siting, design, construction, commissioning and operation is the decommissioning process $[1,2]$. The decommissioning process of nuclear installations is difficult to achieve whatever its type $[3,4]$. The VVR-S nuclear research reactor from Magurele-Bucharest was put into operation in 1957 and was used for the development of the research in physics and nuclear energetic as well as for radioisotopes production. The VVR-S type reactor is a research thermal reactor, using distilled light water as moderator, coolant and reflector (having $2 \mathrm{MW}$ reactor thermal power and an average thermal neutron flux of $\left.10^{+13} \mathrm{n} /\left(\mathrm{cm}^{2} \mathrm{~s}\right)\right)$. This reactor has functioned using lowenriched nuclear fuel (10\%), EK-10 type, until December 1983, and since January 1984, highly enriched fuel (36\%), S-36 type. The reactor functioned until December 1997 in operating regime, then was passed in conservation. In July 2001 the permanent shut-down was decided. The decommissioning of the reactor has started in 2010 and is planned to be finalized in 2020 , being the first nuclear research reactor that has started the decommissioning project from the South-East of Europe.

All amount of the nuclear spent fuel, S-36 and EK-10 type, was returned to Russian Federation (first in 2009 and last in 2012), and the radioactive waste resulted from the reprocessing of it will remain permanently in the Russian Federation. The decommissioning strategy chosen is

*corresponding author; e-mail: dejuradu@yahoo.com immediate dismantling. At this moment, the radionuclides with half-life shorter than 1 year have a minor contribution to the contamination of materials and equipments used in reactor department.

\section{Planning, approval and resources}

The decommissioning activities were authorized by the National Commission for Nuclear Activities Control (CNCAN) which represents the nuclear regulatory authority in Romania, by approving the detailed plan for decommisioning. The financing of the entire project is assured by the Romanian government, through the state budget. The general manager, through the project manager, is responsible for planning, insurance and financial control of the resources needed to satisfy the safety standards, maintaining safety culture, implementing an effective system of integrated management for fulfilling the decommissioning project objectives. Most decommissioning activities are executed with equipment purchased by the institute and operated by own staff. These operators perform demolition operations, dismantling, segmentation and decontamination of the systems, structures, equipment's and components (SSEC) of the nuclear reactor and dispose the radioactive waste to be stored in packages by the National Radioactive Waste Repository. At this moment the primary circuit is decommissioned, the reactor vessel will be the next.

\section{Decommissioning of the primary circuit}

The primary cooling circuit includes: the reactor itself, circulation pumps, heat exchangers, degasser, filter ion exchangers, piping connection, drainage system, and radioactive leaks. Excepting the degasser, the primary 
circuit equipments were placed in the pumps room (basement hall reactor). The operating principle was as follows. The cooling agent (distilled water) enters the active area for taking the heat of the reaction, coming through a pipeline with $\phi=35 \mathrm{~cm}$ till the aspiration pumps. The pumps suppress the cooling agent to the active area through two heat exchangers connected in series. The water returns in pumps, achieving in this way a closed loop of the primary coolant. On each pump suction and discharge, a valve was provided with an electromechanical drive and manual remote. The handling of each valve was done in two halls adjacent to pump room. For normal operation of the reactor at nominal power, three pumps were needed, the other two remain in reserve. From the collector discharge, the cooling agent was sent through a pipeline with $\phi=35 \mathrm{~cm}$ in the two heat exchangers in series. On this pipe a measurement diaphragm was set up to measure the coolant flow through the reactor. On leaving the exchangers, the flow rate of the coolant through the reactor, goes directly into the reactor and another in degasser (20\% of the nominal flow through the reactor). On the upstream and downstream coolant path of the exchanger two remotely operated valves were placed, allowing the isolation of exchangers in case of intervention (only by stopping the primary circuit). The passage from the pumps room to the hall of the nuclear reactor is achieved through two hatches (heat exchangers and the filter) that have access to the bridge crane of 10 tonnes. In the pump room there is mounted a $1 \mathrm{t}$ electric chain hoist and lifting beams. In the entrance hall there is mounted a $1 \mathrm{t}$ electric chain hoist that ensure the access through a hatch to the $5 \mathrm{t}$ hoist from the reactor hall. Through these hatches and lifting equipment all the SSEC decommissioned from the pumps room were evacuated in the hall of the reactor. In this paper the experience gained during the decommissioning [5-8] of the SSEC from the pumps room of the nuclear reactor is reviewed.

\section{Decommissioning of SSEC}

In situ measurements and laboratory measurements were used for radiological characterization of the VVR-S reactor. Three kinds of in situ measurements were performed: dose rate measurements, radioactive contamination measurements and gamma-ray spectrometry. It was found that the pumps room is highly contaminated. This contamination is due to reactor operation. Contamination penetrated into the wall and floor up to a depth of $2 \mathrm{~cm}$. Contamination is concentrated behind pumps and their pedestal. Conforming to spectrometric measurements, the nuclide vector for this room was considered to be $90 \%{ }^{60} \mathrm{Co}$ and $10 \%{ }^{137} \mathrm{Cs}$. The maximum level of the contamination was $23.8 \mathrm{~Bq} / \mathrm{cm}^{2}$ and of specific activity $20.7 \mathrm{~Bq} / \mathrm{g}$. This room must be decontaminated taking into account the contamination depth penetration [9].

\subsection{Decommissionig of the stainless steel tubing of the secondary circuit}

To create a proper work space, in order to access the sections of pipes, was proceeded to the dismantling and evacuation from the pumps room of those sections that are located above the heat exchangers. The crossings embedded pipes of the secondary circuit were cut with oxygen burning at $30 \mathrm{~mm}$ below the wall, at the entrance to the pumps room. Simultaneously, with the dismantling of the pipelines sections, the supports were eliminated from the room. All the materials were released from regulatory control.

\subsection{The evacuation of the heat exchangers}

Before starting the dismantling of the heat exchangers from the pumps room, primary circuit water was emptied. For the dismantling of the two heat exchangers $(5400 \mathrm{~kg} / \mathrm{pcs})$ and plate support $(560 \mathrm{~kg} / \mathrm{pcs})$, the following operations have been performed: (i) the dismantling of the rods remotely operated of the primary circuit valves from the heat exchangers area and heat exchangers covers; (ii) the cutting of the primary circuit flange section with $\phi=300 \mathrm{~mm}$ and $600 \mathrm{~mm}$ length, from the exit from the heat exchanger no. 2 using the pipe cutting MCA and Bevelling machine; (iii) the demolishing of the flanges between the heat exchanger no. 1 and no. 2 and the flanges between valve no. 11 and the heat exchanger no. 1; (iv) the cutting with Hypertherm Powermax 105 CNC plasma cutting machine of the platform around heat exchangers.

In Table I the radiological measurements during the decommissioning process of the heat exchanger before plasma torch cutting are presented.

During the evacuation of the heat exchangers, the following operations have also been performed: (i) the dismantling of the drainage pipes and heat exchangers supports from the floor; (ii) the plasma cutting of approximately $4 \mathrm{~cm}$ from the heat exchangers supports, in order to evacuate them (support and shifter) through the trap between the pumps room and the reactor hall; (iii) successive evacuation of the lids and heat exchangers bodies from the pumps room to the radiological measurements and primary cutting area in the reactor hall using the $10 \mathrm{t}$ crane; (iv) the decontamination of the exchanges leads using DeconGel 1102; (v) the plasma cutting on the circumference of the shell exchangers, at $1 \mathrm{~m}$ below the lid flange and $1 \mathrm{~m}$ above the bottom; (vi) tubular plates cutting into quarters; (vii) the cutting off each quarter of beam pipes under tubular plate using the bandsaw machine Beka-Mak BMSY 440; (viii) the cutting of the tubular beam pipes of $40-60 \mathrm{~mm}$ in length using the Holmatro 3020 cutters.

In Table II the radiological measurements of the pumps from the primary circuit before decommissioning process and after removal of the electrical engines, pumps, stainless steel pipes and vanes are presented.

Although the tubular beam pipes showed a relatively low level of contamination, these have not been decontaminated and were treated as radioactive waste because the decontamination process is not economically justified. 
TABLE I

Radiological measurements during decommissioning of the heat exchanger before plasma torch cutting.

\begin{tabular}{c|l|c|c|c|c}
\hline \hline & & \multicolumn{3}{|c|}{ Direct measurements } & \multirow{2}{*}{ Final } \\
\cline { 3 - 5 } No & \multicolumn{1}{|c|}{ Measurement point } & Dose rate & \multicolumn{2}{|c}{ Contamination $[\mathrm{cps}]$} & \\
\cline { 3 - 5 } destination \\
\hline 1 & inlet, pipe connection & 0.65 & 70 & 20 & \\
2 & upper lid & 0.22 & 20 & $14-17$ & free release \\
3 & heat exchanger body & 0.6 & $135-160$ & $16-21$ & \\
\hline 4 & stainless steel pipes, upper part & $0.44-0.68$ & $58-74$ & $\mathrm{~N} / \mathrm{A}$ & \\
5 & stainless steel pipes, middle part & 1.2 & 98 & $\mathrm{~N} / \mathrm{A}$ & \\
6 & stainless steel pipes, water discharging area & 61 & $80-198$ & $\mathrm{~N} / \mathrm{A}$ & \\
7 & outlet nipple & $94-110$ & 26430 & $\mathrm{~N} / \mathrm{A}$ & radwaste \\
8 & stainless steel rods suport plate, including rust, slag & 20 & $3150-4250$ & $\mathrm{~N} / \mathrm{A}$ & \\
9 & lower lid & $110-150$ & $11720-26430$ & $150-170$ &
\end{tabular}

Radiological measurements during decommissioning of the primary circuit. A — draining channel,

TABLE II A - draining channel, B - concrete pumps platform, C - floor in the pumps room, D - dose rate $[\mu \mathrm{Sv} / \mathrm{h}]$.

\begin{tabular}{|c|c|c|c|c|c|c|c|c|c|}
\hline \multirow[t]{3}{*}{ No. } & \multirow[t]{3}{*}{ Point } & \multicolumn{8}{|c|}{ "Direct measurements [cps] } \\
\hline & & \multicolumn{4}{|c|}{ before starting decommissioning activities } & \multicolumn{4}{|c|}{ after removal of the appliances } \\
\hline & & $\mathrm{A}$ & $\mathrm{B}$ & $\mathrm{C}$ & $\mathrm{D}$ & $\mathrm{A}$ & $\mathrm{B}$ & $\mathrm{C}$ & $\mathrm{D}$ \\
\hline 1 & F1-1 & 154,160 & $\mathrm{~N} / \mathrm{A}$ & 80 & 0.47 & 51,81 & $\mathrm{~N} / \mathrm{A}$ & 18 & 0.11 \\
\hline 2 & F1-2 & 154,160 & $\mathrm{~N} / \mathrm{A}$ & 26 & 0.2 & 45,64 & $\mathrm{~N} / \mathrm{A}$ & 16 & 0.11 \\
\hline 3 & F1-3 & 134 & $\mathrm{~N} / \mathrm{A}$ & 20 & 0.41 & 12,13 & $\mathrm{~N} / \mathrm{A}$ & 16 & 0.11 \\
\hline 4 & F1-4 & 60,87 & $\mathrm{~N} / \mathrm{A}$ & 18 & $\mathrm{~N} / \mathrm{A}$ & 14,14 & $\mathrm{~N} / \mathrm{A}$ & 15,18 & 0.11 \\
\hline 5 & F1-5 & 39,60 & $\mathrm{~N} / \mathrm{A}$ & 17 & 0.8 & 12,13 & $\mathrm{~N} / \mathrm{A}$ & 13,17 & 0.10 \\
\hline 6 & F1-6 & 23,40 & $\mathrm{~N} / \mathrm{A}$ & 32 & $\mathrm{~N} / \mathrm{A}$ & 12,12 & $\mathrm{~N} / \mathrm{A}$ & 13,13 & 0.10 \\
\hline 7 & $\mathrm{~F} 2-1$ & 177,180 & $\mathrm{~N} / \mathrm{A}$ & 120,120 & 0.31 & 38,90 & $\mathrm{~N} / \mathrm{A}$ & 17,18 & 0.11 \\
\hline 8 & $\mathrm{~F} 2-2$ & $\mathrm{~N} / \mathrm{A}$ & 88,140 & 138 & 0.75 & $\mathrm{~N} / \mathrm{A}$ & 14,16 & 16,17 & 0.12 \\
\hline 9 & $\mathrm{~F} 2-3$ & $\mathrm{~N} / \mathrm{A}$ & $\mathrm{N} / \mathrm{A}$ & 25,25 & 0.33 & $\mathrm{~N} / \mathrm{A}$ & $\mathrm{N} / \mathrm{A}$ & 14,15 & 0.11 \\
\hline 10 & F2-4 & $\mathrm{N} / \mathrm{A}$ & $\mathrm{N} / \mathrm{A}$ & 25 & $\mathrm{~N} / \mathrm{A}$ & $\mathrm{N} / \mathrm{A}$ & $\mathrm{N} / \mathrm{A}$ & 18,18 & 0.10 \\
\hline 11 & $\mathrm{~F} 2-5$ & 36,41 & $\mathrm{~N} / \mathrm{A}$ & 27,56 & 2.5 & $\mathrm{~N} / \mathrm{A}$ & $\mathrm{N} / \mathrm{A}$ & 17,19 & 0.10 \\
\hline 12 & F2-6 & 36,41 & $\mathrm{~N} / \mathrm{A}$ & 143 & $\mathrm{~N} / \mathrm{A}$ & $\mathrm{N} / \mathrm{A}$ & $\mathrm{N} / \mathrm{A}$ & 12,13 & 0.10 \\
\hline 13 & F3-1 & 190,230 & $\mathrm{~N} / \mathrm{A}$ & 216,240 & 0.48 & 39,50 & $\mathrm{~N} / \mathrm{A}$ & $18,19^{*}$ & 0.12 \\
\hline 14 & F3-2 & $\mathrm{N} / \mathrm{A}$ & 150,200 & 104,120 & 0.8 & $\mathrm{~N} / \mathrm{A}$ & $14,16^{*}$ & $18^{*}$ & 0.12 \\
\hline 15 & F3-3 & $\mathrm{N} / \mathrm{A}$ & $\mathrm{N} / \mathrm{A}$ & 25,26 & 1.1 & $\mathrm{~N} / \mathrm{A}$ & $\mathrm{N} / \mathrm{A}$ & 16,20 & 0.11 \\
\hline 16 & F3-4 & $\mathrm{N} / \mathrm{A}$ & $\mathrm{N} / \mathrm{A}$ & 866 & $\mathrm{~N} / \mathrm{A}$ & $\mathrm{N} / \mathrm{A}$ & $\mathrm{N} / \mathrm{A}$ & $15,17^{*}$ & 0.10 \\
\hline 17 & F3-5 & $\mathrm{N} / \mathrm{A}$ & $\mathrm{N} / \mathrm{A}$ & 27,192 & 3.5 & $\mathrm{~N} / \mathrm{A}$ & $\mathrm{N} / \mathrm{A}$ & 14,15 & 0.10 \\
\hline 18 & F3-6 & $\mathrm{N} / \mathrm{A}$ & $\mathrm{N} / \mathrm{A}$ & 150,192 & 3.1 & $\mathrm{~N} / \mathrm{A}$ & $\mathrm{N} / \mathrm{A}$ & 14,15 & 0.11 \\
\hline 19 & F4-1 & 190,230 & $\mathrm{~N} / \mathrm{A}$ & 145,360 & 0.5 & 38,73 & $\mathrm{~N} / \mathrm{A}$ & $18,18^{*}$ & 0.13 \\
\hline 20 & F4-2 & $\mathrm{N} / \mathrm{A}$ & 40,150 & 180,240 & 1.3 & $\mathrm{~N} / \mathrm{A}$ & $14,15^{*}$ & $17,18^{*}$ & 0.14 \\
\hline 21 & F4-3 & $\mathrm{N} / \mathrm{A}$ & $\mathrm{N} / \mathrm{A}$ & 26 & 0.5 & $\mathrm{~N} / \mathrm{A}$ & $\mathrm{N} / \mathrm{A}$ & 16,20 & 0.13 \\
\hline 22 & F4-4 & $\mathrm{N} / \mathrm{A}$ & $\mathrm{N} / \mathrm{A}$ & 27 & $\mathrm{~N} / \mathrm{A}$ & $\mathrm{N} / \mathrm{A}$ & $\mathrm{N} / \mathrm{A}$ & 16,19 & 0.11 \\
\hline 23 & F4-5 & $\mathrm{N} / \mathrm{A}$ & $\mathrm{N} / \mathrm{A}$ & 27,43 & 1.5 & $\mathrm{~N} / \mathrm{A}$ & $\mathrm{N} / \mathrm{A}$ & 15,18 & 0.11 \\
\hline 24 & F4-6 & $\mathrm{N} / \mathrm{A}$ & $\mathrm{N} / \mathrm{A}$ & 73,200 & $\mathrm{~N} / \mathrm{A}$ & $\mathrm{N} / \mathrm{A}$ & $\mathrm{N} / \mathrm{A}$ & 15,16 & 0.10 \\
\hline 25 & F5-1 & 220,560 & $\mathrm{~N} / \mathrm{A}$ & 42,220 & $\mathrm{~N} / \mathrm{A}$ & 220,560 & 16,16 & $\mathrm{~N} / \mathrm{A}$ & 3.51 \\
\hline 26 & F5-2 & 74,90 & 48,70 & $\mathrm{~N} / \mathrm{A}$ & $\mathrm{N} / \mathrm{A}$ & 74,90 & $16,18^{*}$ & 19,24 & 0.30 \\
\hline 27 & F5-3 & 36,63 & $\mathrm{~N} / \mathrm{A}$ & 34 & $\mathrm{~N} / \mathrm{A}$ & 36,63 & $\mathrm{~N} / \mathrm{A}$ & 18,20 & 0.16 \\
\hline 28 & F5-4 & 33,63 & $\mathrm{~N} / \mathrm{A}$ & 26,28 & $\mathrm{~N} / \mathrm{A}$ & 33,63 & $\mathrm{~N} / \mathrm{A}$ & 16,18 & 0.15 \\
\hline 29 & F5-5 & 54,73 & $\mathrm{~N} / \mathrm{A}$ & $\mathrm{N} / \mathrm{A}$ & $\mathrm{N} / \mathrm{A}$ & 27,56 & $\mathrm{~N} / \mathrm{A}$ & 16,17 & 0.15 \\
\hline 30 & F5-6 & 50,140 & $\mathrm{~N} / \mathrm{A}$ & 50,65 & $\mathrm{~N} / \mathrm{A}$ & 21,23 & $\mathrm{~N} / \mathrm{A}$ & 16,36 & 0.12 \\
\hline 31 & F6-1 & 100,180 & $\mathrm{~N} / \mathrm{A}$ & 48 & 12.6 & 70,180 & $\mathrm{~N} / \mathrm{A}$ & 20,24 & 0.16 \\
\hline 32 & F6-2 & 24,91 & $\mathrm{~N} / \mathrm{A}$ & 34,200 & 2.6 & 17,34 & $\mathrm{~N} / \mathrm{A}$ & 17,36 & 0.16 \\
\hline
\end{tabular}

background: 4 cps, measurement equipment: Berthold UMO LB 123, with probes LB1231 and LB 1236,

*Concrete bricks removed $(30-60 \mathrm{~cm}$ depth) 


\subsection{The evacuation of pumps, couplings, engines and primary circuit piping}

Before dismantling the pumps, the electric motors were dismantled and the following operations were executed: (i) the emptying of the oil pump; (ii) the dismantling of the flanges between the suction collector pipes from the primary circuit and flanges between pumps and collector discharge pipes of the primary circuit, cooling pipes pumps, stainless steel sleeves associated to the pumps and screws between pumps and foundation; (iii) the pumps anchoring in the $1 \mathrm{t}$ monorail and the transport of them in the radiological measurements area; (iv) the dismantling of the screws associated with pumps support; (v) the anchoring of the pumps support in the $1 \mathrm{t}$ monorail and the transport of them to the radiological measurements area.

\subsection{The demolishing and the evacuation of valves and valve driving mechanism}

Before removing the primary circuit components setup on the left side of the room, it was proceeded to the removal of the remote actuators of valves, sections, and auxiliary components. In order to access to the fasteners of the pipes sections, the sections dismantled were removed from the room. During the dismantling, temporary supports were used to maintain the parts left in console (suction/discharge collectors).

\subsection{The dismantling and the evacuation of the aluminium pipes to the nozzles from below the reactor vessel}

For the dismantling of the aluminum pipes from the primary circuit, the next actions were done: (i) the scaffold work was mounted at a specific height in the area of the aluminum pipes from the pumps room; (ii) the cutting of the aluminum pipes ends (are coming out through the concrete biological protection in the pumps room) using the pipe cold cutting machine GBC 2700; (iii) the pipes cut were anchored in the $1 \mathrm{t}$ monorail and were transported to the radiological characterization area; (iv) at the same time with the demolishing of the concrete biological protection from rooms no. 30 and 31, the aluminium pipelines from the under reactor vessel were cut; (v) in the room 30 no. (under the reactor) the scaffold and manual hoists for anchoring the aluminum pipelines were mounted; (vi) the flange screws were removed from under reactor and the support pipes clamps has been weakened; (vii) the hoists has been weakened until the pipes ricked the floor; (viii) the pipelines were anchored in the $1 \mathrm{t}$ monorail and then were transported in the radiological measurement area; (ix) the pipelines sections ends were covered with $\mathrm{PE}$ foil and were evacuated using the $10 \mathrm{t}$ crane and the access hatch between the pumps room and the hall of the nuclear reactor ; $(\mathrm{x})$ the pipelines were transferred to the removable modular enclosure for cutting with Proma Bandsaw Machine BMSY 440; (xi) the pipelines were cut into $40 \mathrm{~cm}$ sections and were placed in metal containers.

\subsection{The decommissioning of the mixed bed filter including its biological protection}

The evacuation of the filter was done after the dismantling of the connecting flange bolts between the filter, primary circuit, and the noxious water drainage system. The filter was removed with its protection, through the trap filter, using the $10 \mathrm{t}$ bridge crane, in the reactor hall, in the dismantling and prime cuttings areas. Then, the first 2 iron rings of protection, the upper lid and the nozzle support disc were dismantled. Radiological measurements were done and smears were collected from the surface of the dismantled parts for measuring with gamma-ray spectrometry systems with HPGe detector. Measurement of surface contamination and gamma dose rate were carried out using LB 123 UMo Berthold universal monitor and dedicated probes, e.g. LB1231, LB1236. In Table III the measurements results are presented. It has been observed that the maximum dose rate was presented in the upper side of the filter.

The next step was to transfuse the filtering mass (resin and graphite) in 4 barrels of $220 \mathrm{~L}$ with concrete and plastic protection. The removal of the filter mass within the filter was done from distance using long-tailed soffit of about $2 \mathrm{~m}$. The amount of filter mass introduced into a container was conditioned by the dose rate $(2 \mathrm{mSv} / \mathrm{h})$ from the wall of the container. The results of the dose rate measurements from near and from $1 \mathrm{~m}$ from the wall of the containers are presented in Table IV. The dose rate received by an operator during the evacuation of the filter mass from the filter did not exceed $60 \mu \mathrm{Sv}$ /day.

The containers with filter mass resulted following filter dismantling from the primary circuit are temporarily stored in an intermediate storage until neutralization. Periodically, each 2 months, these are monitored by the dosimetry. The next step was to remove the remaining protective rings and to repeatedly wash the vessel when is emptied. After the resin and the graphite were removed, contaminated areas were identified, especially in the upper side of the vessel. The vessel was cut with plasma machine inside the lined stainless steel cutting room. The decontamination was done using DeconGel 1102. After two consecutive cycles of decontamination was done, five areas with count rate about $50 \mathrm{cps}$ each were still left there. The contaminated areas from the stainless steel vessel were cut with plasma machine and treated as radioactive waste.

\subsection{The dismantling of the drain system steel pipelines from the pumps room}

The operation was quite complicated. The pipelines of the drain system were cut in their initial position using the pipe cold cutting machines GBC 2700 and the plasma jet cutting machine. The drain pipes were removed from the gutter from the pipes room using the $1 \mathrm{t}$ monorail and the manual hoist. The ends of the pipelines sections corresponding to the primary circuit draining were wrapped with $\mathrm{PE}$ foil. The pipelines sections were evacuated from the pumps room in 
TABLE III

Radiological measurements during decommissioning of the primary circuit filter. A - cont. [cps], B - dose rate [ $\mu$ Sv $/ \mathrm{h}]$.

\begin{tabular}{|c|c|c|c|c|c|c|c|}
\hline \multirow[b]{3}{*}{ No. } & \multirow[b]{3}{*}{ Measurement point } & \multicolumn{4}{|c|}{ "Direct measurements } & \multirow{2}{*}{\multicolumn{2}{|c|}{ Activity $[\mathrm{Bq}]$}} \\
\hline & & \multicolumn{2}{|c|}{ before dism. } & \multicolumn{2}{|c|}{ after dism. } & & \\
\hline & & $\mathrm{A}$ & $\mathrm{B}$ & $\mathrm{A}$ & $\mathrm{B}$ & ${ }^{137} \mathrm{Cs}$ & ${ }^{60} \mathrm{Co}$ \\
\hline 1 & filter lid, upper side & 13 & 0.3 & 12 & 0.14 & $<3.01$ & $<3.55$ \\
\hline 2 & filter lid, lower side & 18.4 & 70 & 13 & 68 & $<2.86$ & $<3.12$ \\
\hline 3 & ring no. 2 , lower front side & 12.5 & $\mathrm{~N} / \mathrm{A}$ & 13 & 0.1 & $<3.02$ & $<3.57$ \\
\hline 4 & ring no. 2 , inside & 14.5 & 1.66 & 14 & 20 & $<3.01$ & $<3.56$ \\
\hline 5 & ring no. 3 , lower front side & 13 & 1.71 & 18 & 0.11 & $<2.86$ & $<3.12$ \\
\hline 6 & ring no. 3 , inside & 15.5 & 0.14 & 15 & 0.14 & $<3.02$ & $<3.58$ \\
\hline 7 & ring no. 4 , lower front side & 22 & 0.17 & 20 & 0.13 & $<3.00$ & $<3.53$ \\
\hline 8 & ring no. 4 , inside & $35-46$ & 0.48 & 18 & 0.11 & $<2.86$ & $<3.12$ \\
\hline 9 & stainless steel vessel lid, upper side & 46 & 1.66 & 13 & 0.28 & $<2.99$ & $<3.49$ \\
\hline 10 & stainless steel vessel, inside & 245 & 2.15 & $\mathrm{~N} / \mathrm{A}$ & $\mathrm{N} / \mathrm{A}$ & $<3.04$ & $<3.44$ \\
\hline 11 & stainless steel vessel lid, lower side & 39 & 0.71 & 35 & 0.7 & $\mathrm{~N} / \mathrm{A}$ & $\mathrm{N} / \mathrm{A}$ \\
\hline 12 & stainless steel vessel, inside bottom & 245 & 2.15 & 7 & 0.12 & $\mathrm{~N} / \mathrm{A}$ & $\mathrm{N} / \mathrm{A}$ \\
\hline 13 & nozzles support plate & $21-90$ & $\mathrm{~N} / \mathrm{A}$ & $21-90$ & $\mathrm{~N} / \mathrm{A}$ & $\mathrm{N} / \mathrm{A}$ & $\mathrm{N} / \mathrm{A}$ \\
\hline 14 & nozzles & $20-67$ & $\mathrm{~N} / \mathrm{A}$ & $20-67$ & $\mathrm{~N} / \mathrm{A}$ & $\mathrm{N} / \mathrm{A}$ & $\mathrm{N} / \mathrm{A}$ \\
\hline 15 & stainless steel vessel after removing the resin & $\mathrm{N} / \mathrm{A}$ & $10^{6}$ & $\mathrm{~N} / \mathrm{A}$ & $\mathrm{N} / \mathrm{A}$ & $<2.86$ & $<3.12$ \\
\hline 16 & stainless steel vessel after the first decontamination cycle & $\mathrm{N} / \mathrm{A}$ & $1.6-2$ & $\mathrm{~N} / \mathrm{A}$ & $\mathrm{N} / \mathrm{A}$ & $\mathrm{N} / \mathrm{A}$ & $\mathrm{N} / \mathrm{A}$ \\
\hline 17 & stainless steel vessel after the second decontamination cycle & $\mathrm{N} / \mathrm{A}$ & 320 & 50 & 0.4 & $\mathrm{~N} / \mathrm{A}$ & $\mathrm{N} / \mathrm{A}$ \\
\hline 18 & stainless steel vessel after plasma torch cutting & 50 & 86 & $18-50$ & 0.3 & $\mathrm{~N} / \mathrm{A}$ & $\mathrm{N} / \mathrm{A}$ \\
\hline 19 & rings no. $5-10$, lower side & $38-85$ & 0.58 & 20 & 0.18 & $\mathrm{~N} / \mathrm{A}$ & $\mathrm{N} / \mathrm{A}$ \\
\hline
\end{tabular}

the reactor hall and cut at the length of $40 \mathrm{~cm}$ using the mechanical Proma Bandsaw Machine BMSY 440. The radiological monitoring of the resulted waste was done.

\subsection{The dismantling of stainless steel pipes and valves from the primary circuit}

The fastening systems of valves and stainless steel pipes were removed one at a time and let down on the floor using manual hoists, pallet trucks hoist or $1 \mathrm{t}$ monorail. To remove the primary circuit piping and valves, the scaffold working at height and hydraulic work platform were installed in the pumps room. Part of the steel pipes were cut in the original position using the pipe cold cutting machines GBC 2700 or the pipe cutting and Bevelling machine MCA 6 for orbital cutting. The pipes which could not be cut in the original position or those with a large diameter were being transferred to the removable modular enclosure for cutting with Proma Bandsaw Machine BMSY 440. The stainless steel pipes and valves from the primary circuit were evacuated from the pumps room and the RN hall and together with the heat exchangers were free released from regulatory control.

All the components of valves from the primary circuit were dismantled and all the contaminated parts were decontaminated. Sections of pipes cut to a length of $40 \mathrm{~cm}$ were inserted into metal containers. The dosimetric measurements, cutting in sections, sorting, handling and temporary storage of waste resulted from the primary circuit will be done at a time, in a disassembling order, in the reactor hall inside the wrecker and primary cutting. During the evacuation sections, these were protected with
$\mathrm{PE}$ foil or polyethylene bags to prevent contamination evacuation route.

TABLE IV

Radiological measurements of the resin filled containers (220 l drums).

\begin{tabular}{c|c|c|c}
\hline \hline \multirow{2}{*}{ No. } & & \multicolumn{2}{|c}{ Dose rate $[\mu \mathrm{Sv} / \mathrm{h}]$} \\
\cline { 3 - 4 } & Drum code & contact & at $1 \mathrm{~m}$ \\
\hline 1 & $\mathrm{R} 203$ & 1628 & 300 \\
2 & $\mathrm{R} 204$ & 106 & 96 \\
3 & $\mathrm{R} 205$ & 48 & 20 \\
4 & $\mathrm{R} 206$ & 12 & 0.3
\end{tabular}

\subsection{The drainage system}

The drainage system is provided both for collecting and storage in special tanks of the contaminated distilled water resulted from the drainage of the equipment (pumps, heat-exchangers or from the spent fuel pond drainage) or the drainage of the reactor (the protection vessel and even the primary system drainage). This system is mainly located in the radioactive wastes drainage system existing in the primary system of the pump house, except the overflow pipe coming from the deaerator, as well as of the collecting pipe crossing the main building along the "E" is up to the building of the "contaminated water valve" into a damping tank of $30 \mathrm{~m}^{3}$.

\section{The radioactivity monitoring}

The radiological monitoring of personnel and equipment used was performed interphasic: before starting 
the work, during the dismantling assemblies, after carrying out the decontamination tests, while performing the sorting operations from the viewpoint of radiological contamination presence (materials or equipments released under the regulatory control or materials treated as radioactive waste, all done in accordance with the applicable procedures).

The waste resulted from the decommissioning of the SSEC from the pumps room are quantified in Table V.

\section{TABLE V}

The actual situation of the radioactive waste removed from the nuclear installation in the pumps room.

\begin{tabular}{l|c|c}
\hline \multirow{2}{*}{\multicolumn{1}{c|}{ Material }} & Total & Free released \\
\cline { 2 - 3 } concrete rubble & \multicolumn{2}{|c}{ mass [kg] } \\
concrete & 1790 & 86 \\
OLC, cast iron & 13320 & 15889 \\
stainless steel, OLC & 25236 & 4938 \\
lead & 180 & 6151 \\
metal, plastic & 825 & 180 \\
copper wire, steel & 23 & 0 \\
copper & 148 & 0 \\
aluminum & 315 & 0 \\
resin & 186 & 0
\end{tabular}

The equipments and components from the pumps room are contaminated both inside and outside. The outer contamination is due to leaks and airborne contamination and the inner contamination results from the contact with water from the primary circuit. The level of contamination cannot be easily estimated because the removal tests and the measurements of the contamination level for the outer surfaces are not yet available. Based on the experience from other decommissioning projects, it can be estimated the inner contamination that can reach in some places up to hundreds of $\mathrm{Bq} / \mathrm{cm}^{2}$, while the outer contamination may reach some $\mathrm{Bq} / \mathrm{cm}^{2}$. The contamination can be reduced up to $20 \%$ by eliminating the removable contamination. The waste products were manipulated between two successive phases of work been packaged in PE bags for ambient environmental protection. The demolition robots Brokk 50 and Brokk 160 were used in order to remove the contaminated areas around pumps and leaks collector channel. After the evacuation of the primary circuit components from the pumps room and dismantling of biological protection between rooms 30 and 31, the pumps room becomes available for decontamination and for finishing the restoration.

The presence of the aerosols in the work areas was monitored with AMS-4 Beta Air Monitor for early warning to exposure from beta particulate, radioiodine or noble gases. The FHT 2000 AERD Alpha/Beta Monitor was also used for continuous monitoring of aerosol-bound artificial alpha and beta activity concentrations found in the work stations. Gamma-ray spectrometry technique was used to identify quantitative and qualitative the gamma radiation.

\section{Experiences and knowledge}

One problem encountered during the dismantling of the heat exchangers was that, although water has been cleared through the draining tubes into the bundles of pipes (pipe in pipe), this could not be eliminated entirely. The procedure which could be emptied out all the water was through tilting (overturns) using the overhead crane. All the water was collected in the drainage system and radioactive leaks. A major problem was the dismantling of the steel pipes with a diameter of $40 \mathrm{~cm}$ embedded in the heavy concrete walls that pass towards degasser. The heavy concrete has in composition metallic elements (nuts, screws, balls, etc.), composition extremely hard to smash. For long pipes, embedded in the wall with a sinuous way, which are contaminated inside and cannot be easy decontaminated, the decommissioning put serious challenges. Due to the pumps room configuration and the placement of the equipments and pipelines that makes the primary circuit, the existing high systems do not cover the whole pumps room. Anchors and fixing devices were built additionally in order to achieve the demolishing, dismantling and the materials evacuations from the pumps room. Because of the gauge on site, some of the components were cut. It was found that the lifting systems need to be conceived since the design phase of the nuclear installation. During the pipelines cutting, places with limited accessibility have required the use of various techniques of cutting (orbital saws, pendular saws, oxyacetylene, etc.) having as consequences the increase of financial resources.

\section{Lessons learned}

From these decommissioning activities many lessons are learned. During decommissioning process it is preferably to use personal with experience, if it is possible, operators of the nuclear installation with multidisciplinary skills. The decommissioning activities need to be planned in detail. The decommissioning elements need to be established from the design phase of the nuclear installation. Personnel should be trained periodically with the provisions of applicable procedures. Any additional cycle training is not superfluous. Practical training on mockups can be performed repeatedly by staff. The decommissioning techniques can be used in this way to optimize as much as possible the working time and acquiring the necessary automatism. These procedures have the effect of reducing the working time and consequently the collected dose. Also, it is necessary to learn from experience and mistakes of others, as well as increase of the capability of technical support staff by scheduling visits to other similar nuclear installations which are in decommissioning process. The decommissioning of the long sections of pipes which are embedded may raise serious technical problems. They are very difficult to decommission and decontaminate. The caution should be at every step in the decommissioning operations. Unexpected things of mechanical, electrical or radiological nature can happen. There is nothing more precious than the health 
and safety of the operating personnel. The water is not recommended to be used in the decommissioning process because this leads to the production of additional radioactive waste. It is not necessary complicating the decommissioning operations more than they already are. Lessons learned must be shared with other entities by organizing workshops coordinated by IAEA and other nuclear entities.

\section{Acknowledgments}

The authors offer many thanks to their colleagues from the Reactor Decommissioning Department, IFIN-HH, for their support and assistance.

\section{References}

[1] V. Ljubenov, D. Nikolić, M. Pešić, M. Milošević, L.J. Kostić, M. Steljić, O. Šotić, D. Antić, in: Proc. Fifth Yugoslav Nuclear Society Conf. YUNSC, 2004.

[2] V. Massaut, in: Proc. 5th Int. Conf. on Decommissioning of Nuclear Facilities, London, 1997.
[3] T. Gilmore, C. DeWitt, D. Miller, K. Colborn, in: Proc. WM2012 Conf., Phoenix (USA), 2012.

[4] M. Klein, Y. Demeulemester, S. Moers, M. Ponnet, Management routes for materials arising from the decommissioning of a PWR reactor, IAEA-SM-357/2.

[5] D. Peter, Dismantling Techniques, EUNDETRAF, Mol, Belgium 2002.

[6] L.E. Boing, in: Argonne National Laboratory, Advisory Committee on Nuclear Waste, Working Group Meeting on Decommissioning Lessons Learned, Rockville (USA), 2006.

[7] K. Lauridsen, N. Strufe, in: Danish Decommissioning IDN Annual Forum, IAEA, Vienna, 2009.

[8] E. Wiese, in: IAEA/USA Interregional Training Course on Decontamination and Decommissioning of Research Reactors and Other Small Nuclear Facilities, Argonne National Laboratory (USA), 1998, Lecture \#5B-5C.

[9] M. Klein, V. Massaut, H. Aït Abderrahim, R. Mandoki, C. Plateau, E. Rousseau, in: Proc. Spectrum 98, Int. Conf. on Decommissioning and Decontamination and on Nuclear and Hazardous Waste Management, Denver (USA), 1998, American Nuclear Society. 